\title{
CONSTITUCIONALISMO DIRIGENTE NO BRASIL: EM BUSCA DAS PROMESSAS DESCUMPRIDAS*
}

Nelson Camatta Moreira

\begin{abstract}
A Constituição de 1988, boa ou má, aplaudida ou recriminada, mais remendada pelo presente governo que capa de mendigo é, queiram ou não os seus adversários, a derradeira âncora, como já se disse, que ainda temos à mão nesse regime de medidas provisórias para tolher $\mathrm{o}$ naufrágio das instituições em mar onde flutuam já os destroços da lei, da moral administrativa e da legitimidade do poder. Vamos, portanto, salvar a Constituição. (PAULO BONAVIDES)
\end{abstract}

\section{RESUMO}

Propõe, no texto subseqüente, como condição fundante de um projeto estruturador de um constitucionalismo-dirigente "à moda brasileira", a necessária construção hermenêutica de um paradigma jurídico pautado por uma ética includente (oposta ao modelo neoliberal globalizante), com uma concepção de reconhecimento extensiva a todos os membros da comunidade política. Para tanto, num primeiro momento, é necessário que se reconheça a carga valorativa da ordem constitucional brasileira. Em seguida, aborda o projeto dirigente que esta ordem sugere como contribuição para a afirmação da dignidade humana no Brasil. Por fim, enfrenta o problema da ausência de um sentimento constitucional capaz de fomentar o projeto dirigente e, conseqüentemente, a efetivação do texto de 1988.

* O tema proposto neste texto repercute parcialmente os resultados da pesquisa desenvolvida para a elaboração de tese de Doutoramento em curso na UNISINOS-RS (Brasil), com estágio anual (2007) na UNIVERSIDADE DE COIMBRA (Portugal), apoiado pela CAPES.

** Mestre e doutorando em Direito na Universidade do Vale do Rio dos Sinos (UNISINOS-RS); pesquisador, bolsista modalidade I, do Centro de Aperfeiçoamento de Pessoal de Nível Superior; professor universitário; advogado. 
Palavras-chave: Constitucionalismo dirigente. Dignidade humana. Cidadania. Sentimento constitucional

\section{ABSTRACT}

In the subsequent text, one proposes, as a founding condition in a structuring project of a directing constitutionalism "to the Brazilian way", the necessary hermeneutic construction of a legal paradigm ruled by a including ethic (opposite to the globalizing neo-liberal model), with a conception of extensive recognition to every members of the political community. Therefore, in a first moment, it is needed that one recognizes the worthy burden of Brazilian Constitutional order. Afterwards, one approaches the directing project that this order suggests as a contribution for the assertion of the human dignity in Brazil. At last, one faces the problem of a constitutional feeling's lack able to encourage the directing project and, consequently, the effectiveness of the 1988 text.

Keywords: Directing constitutionalism. Human dignity. Citizenship. Constitutional feeling.

\section{INTRODUÇÃO}

$\mathrm{O}$ ideal de um constitucionalismo dirigente consiste numa construção interpretativa, que teve como base normativa o texto da Constituição portuguesa de 1976, elaborada por Canotilho, que, por sua vez, defende, em síntese, a superação da noção da existência de normas meramente programáticas advindas do texto constitucional, pregando a importância dos princípios e da materialidade da Constituição (CANOTILHO, 2001).

Transportando para a realidade periférica brasileira, alguns autores $^{1}$ sugerem a sedimentação, no campo jurídico, de um "constitucionalismo dirigente adequado a países de modernidade tardia": como tentativa de defesa diante dos devastadores "ataques neoliberais" ao Estado brasileiro e de luta pela proteção dos direitos fundamentais - previstos na Constituição Federal de 1988 e nos tratados internacionais de direitos humanos ratificados pelo Brasil - e pela contínua construção da democracia.

É importante frisar que, no paradigma que antecede à noção de Constituição programático-dirigente, o texto constitucional era 
entendido como um terceiro elemento que se interpunha entre o sujeito (filosofia da consciência) e o objeto (a sociedade). A linguagem constituinte, da busca do novo, da emancipação da sociedade, da busca da afirmação da dignidade - defendendo-se/implementandose direitos fundamentais -, “[...] do resgate de promessas da modernidade, dramaticamente sonegadas em países periféricos como o Brasil, passa a ser, no interior do novo paradigma, condição de possibilidade desse novo" (STRECK, 2004), pois, na tradição engendrada pela noção de Estado Democrático de Direito, não se configura mais um constitucionalismo de cariz liberal, mas, sim, um constitucionalismo hermeneuticamente construído em um "novomodo-de-ser, instituído pelo pacto constituinte, que estabelece os limites do mundo jurídico-social" (STRECK, 2004).

Na verdade, "[...] não há uma Teoria da Constituição, mas várias Teorias da Constituição, adequadas à sua realidade concreta" (BERCOVIVI, 2004, p. 265). Daí, então, exsurge a noção acerca da continuidade do projeto de um constitucionalismo dirigente (e não de o constitucionalismo dirigente) (COUTINHO, 2005) moldado - a partir do movimento constituinte pós-ditadura militar no Brasil - de acordo com as características/necessidades pátrias, logicamente inseridas também num contexto de transformações globais.

A idéia é, então, trabalhar uma teoria da constituição adequada a um país periférico, como o Brasil - no qual o Estado social foi um simulacro -, e que sofre com o impacto da globalização neoliberal. Ou seja, é preciso assegurar, ainda que com grandes dificuldades, um núcleo mínimo valorativo, construído/reconhecido sóciohistoricamente, a fim de se evitar aquilo que Marcelo Neves chama de "desconstitucionalização fática" ou "concretização desconstitucionalizante" que,

[...] nos âmbitos das 'Constituições nominalistas' dos países periféricos, destacando-se o Brasil, atua no sentido da manutenção do status quo social. Serve à permanência das estruturas reais de poder, em desacordo com o modelo textual de Constituição, cuja efetivação relevante importaria profundas transformações sociais (NEVES, 1995, p. 158).

A partir de um viés hermenêutico-filosófico, a Constituição pode ser entendida como um conjunto de valores compartilhados por 
determinada comunidade política, cabendo ao intérprete revelar à sociedade o seu existir comunitário. E esse processo de revelação não se faz possível, no campo jurídico, principalmente, quando não há a devida adaptação de teorias importadas desde modelos centrais.

Esse é o grande desafio, portanto, que se segue enfrentado pelo texto subseqüente: a discussão acerca dos pressupostos da teoria constitucional-dirigente, com fundamentação filosófica, inserida num contexto global extremamente complexo.

\section{A CONSTITUIÇÃO BRASILEIRA COMO ORDEM DE VALORES SUBSTANTIVOS}

Considerando-se a função reguladora assumida pelo Estado moderno, o direito - como ordem jurídica (im)posta - acaba se tornando sinônimo de lei, que, por sua vez, passa a ser considerada simplesmente um comando do soberano. Ela é identificada como jurídica pela sua origem, e não pelo conteúdo. Ou seja, ela pode ser "justa" ou "injusta" sem que isso afete a sua qualificação jurídica. Daí a noção weberiana de que, no positivismo jurídico, qualquer direito pode criar-se e modificar-se por meio de um estatuto sancionado corretamente quanto à forma (ROTH, 1998). Assim,

Um sistema de regras é formal na medida em que permite que seus intérpretes, oficiais ou não, justifiquem as suas decisões mediante referência às próprias regras e à presença ou ausência dos fatos enumerados pelas regras, sem consideração de quaisquer argumentos de justiça ou utilidade (UNGER, 1979, p. 214).

Habermas (1992), analisando Weber, aduz, então, que o Direito passa a ser, precisamente, aquilo que um legislador político (independente de ele ser ou não, democraticamente, legitimado) delibera como direito, de acordo com um procedimento legalmente institucionalizado.

O positivismo, nessa fase, parte das leis ou, subsidiariamente, de outras tantas normas sociais da ordem estatuída numa espécie de hierarquia que culmina em ordenamento único, pleno, hermético e consagrado sob a égide estatal. As raízes sociais, a dinâmica dos grupos e das classes não entram em linha de conta, ou ficam atadas 
e limitadas, pois, em todo caso, prevalece a voz do Estado. Nessa perspectiva, o Direito não existe antes do Estado e não paira acima dele (WOLKMER, 1995).

Em Kelsen (1984), já no século XX, esse modelo liberal-positivista vai encontrar a sua proposta mais avançada, na medida em que se concebe que o Direito deve ser definido como norma que, por sua vez, constitui-se no objeto da ciência do direito. Para esta, o estudo da lei deve se dar em "sua pureza", separado de qualquer influência moral, sociológica, psicológica ou filosófica. O neopositivismo lógico kelseniano ${ }^{2}$ nasce, no campo jurídico, do esforço de transformar o estudo do Direito numa verdadeira e adequada ciência que tivesse as mesmas características das ciências físico-matemáticas e naturais.

Na busca pela segurança e previsibilidade nas relações sociais, conceitua-se o fenômeno jurídico em relação à moral e à política de maneira "autônoma", recusando-se a justiça e a eficácia como critérios de juridicidade, de modo que o positivismo deverá elaborar o seu próprio critério do que é jurídico. Esse será a "validade". ${ }^{3}$

Destarte, no âmbito da interpretação e da aplicação da norma jurídica, as possibilidades de discussões acerca da justiça ou da ética são expurgadas na medida em que a tarefa do jurista, em especial do juiz, consiste na mera aplicação da lei ao caso concreto. Não se discutem, portanto, requisitos éticos de validade da lei ou, mesmo, a justiça no caso concreto. Sobre isso, Bobbio (1995, p. 136) afirma:

A validade de uma norma jurídica indica a qualidade de tal norma, segundo a qual existe na esfera do direito ou, em outros termos, existe como norma jurídica. Dizer que uma norma jurídica é válida significa dizer que tal norma faz parte de um ordenamento jurídico real, efetivamente existente numa dada sociedade.

Dentre os mitos compartilhados pelo positivismo jurídico, os mais aceitos e consolidados são os dogmas da coerência, da completude e da unidade do ordenamento jurídico, vetores para a consolidação dos propósitos da segurança e certeza jurídicas exigidos pela sociedade de mercado. O Direito positivo é pressuposto como auto-suficiente, preciso e claro; nele todos os conflitos e fatos ocorrentes no mundo da vida encontram a possibilidade de um enquadramento lógicodedutivo. 
Quanto à atividade interpretativa, tanto em seu momento teórico quanto no decisório, seria uma atividade dedutiva, que revelaria caminhos lógicos tendentes a explicitar a racionalidade profunda do sistema de direito positivo. "Criam, pois, uma ilusão, ou uma aparência de realidade, em relação a duas afirmações fictícias: a de que a ordem jurídica oferece segurança e, depois, que o legislador é sempre racional em suas determinações e prescrições" (WARAT, 1994, p. 53).

Todavia, deve-se registrar que esse modelo liberal-individualistanormativista ${ }^{4}$ sofreu algumas alterações, no âmbito da teoria do Direito, que acompanharam as transformações estatais. Na passagem do Estado liberal para o Estado social, dois tipos de influência imediata podem ser destacadas. O primeiro tipo refere-se à “[...] rápida expansão do uso de normas ilimitadas e de cláusulas gerais na legislação, administração e jurisdição" (UNGER, 1979, p. 204), como se pode identificar na reaproximação entre Estado e Sociedade (garantias de direito sociais, interferência mais intensa do Estado na economia, etc.). O segundo tipo de impacto do Estado Social sobre o Direito é a "[...] transição de estilos de raciocínio legais formalistas para estilos teleológicos ou prudenciais, da preocupação com a justiça formal para um interesse na justiça processual e substantiva."

O Estado Social, identificado a partir do século XIX, trouxe, principalmente em países como, a exemplo, Alemanha e o México, uma proposta de (re)discussão do Direito no qual prevaleceria o raciocínio jurídico teleológico e as preocupações com a justiça distributiva. Com isso, "[...] o estilo do discurso jurídico passa a se assemelhar ao do argumento comum da política ou da economia. Todos se caracterizam pelo predomínio do racionalismo instrumental sobre outras formas de pensamento" (UNGER, 1979, p. 209).

Mas, apesar dessas propostas, a maneira de se operacionalizar o Direito no convívio social ou, dito de outra forma, o modo de produção do Direito $^{5}$ segue influenciado preponderantemente pelo modelo liberal-individual-normativista, o que, por sua vez, acaba gerando - juntamente com outros fatores, por exemplo, a globalização e seus efeitos deletérios - uma dificuldade de efetivação dos direitos humanos em sua plenitude polidimensional (direitos civis, políticos, econômicos, sociais, comunicacionais, dentre outros). 
O que se verificou ao longo da modernidade, principalmente no século XX, foi uma espécie de "vitória" de ideologias forjadas sob discursos formalistas ${ }^{6}$ sobre dois dos principais ideais do Estado Social, quais sejam a eqüidade e a solidariedade.

Dizia Orwell (1998):

Enquanto escrevo, seres humanos altamente civilizados estão sobrevoando, tentando matar-me. Não sentem qualquer inimizade por mim como indivíduo, nem eu por eles. Estão apenas 'cumprindo o seu dever', como se diz. Na maioria, não tenho dúvida, são homens bondosos e cumpridores das leis, que na vida privada nunca sonhariam em cometer assassinato. Por outro lado, se um deles conseguir me fazer em pedaços com uma bomba bem lançada não vai dormir mal por causa disso. Está servindo ao seu país, que tem o poder de absolvê-lo do mal.

O exemplo da Guerra moderna, em especial da Segunda, serve apenas para reforçar o panorama de predomínio da técnica e do formalismo que marcaram a racionalidade do século XX. Essa ideologia, paradoxalmente, acompanhou o processo de afirmação (e de negação) dos direitos fundamentais, bem como do constitucionalismo no século passado.

Questões envolvendo a ética com a política e o direito - a partir da segunda metade do século XX - tornaram-se objeto de investigação de juristas e filósofos do Direito, no intento de superar o hermetismo positivista delimitado alhures. No âmbito jurídico, dois fatores marcaram esse resgate ético: a expansão da proteção normativa internacional dos direitos humanos, no pós II Guerra, e a difusão de Constituições impregnadas de ideais democráticos, principalmente em países marcados pelo autoritarismo, como foram, por exemplo, os casos de Portugal e Espanha, na Europa, e o Brasil, juntamente com os demais países latino-americanos, todos na segunda metade do século XX. Esses dois fatores jurídicos (Tratados e Constituições), na verdade, são apenas espelhos das preocupações contemporâneas com fenômenos que vêm marcando um novo período do convívio humano - iniciado aproximadamente a partir da segunda metade do século XX e que ainda se encontra em aberto.

Tais fenômenos deveram-se ao reconhecimento de tormentosa complexidade das relações sociais, principalmente, a partir da segunda 
metade do século XX. Nesse período, o convívio humano foi abalado por diversos impactos, tais como: o avanço tecnológico em todas as áreas de conhecimento; a insurgência de novos valores e direitos que se tornaram parte integrante do receituário axiológico da democracia de massas; e, ainda, as transformações do processo político “[...] permeável às condicionantes de uma nova ordem internacional que, longe de estabilizar o convívio das nações e melhorar a qualidade de vida dos povos do planeta, apresenta novos desafios e angústias para a humanidade" (CASTRO, 1999, p. 103).

Tudo isso, com a presença de um ingrediente complexo que é a globalização, em suas diferentes feições, acaba levando

[...] à perda de autonomia, com reflexos negativos na capacidade de ação democrática, sob a forma de: a) perda de competências de controle (ou seja de defesa do cidadão contra efeitos de ações de agentes externos, sejam empresas, outros governos ou organismos intergovernamentais); b) déficit de legitimação (pois o círculo dos que participam das decisões democráticas não corresponde aos afetados pelas decisões) e

c) incapacidade de realizar políticas sociais com eficácia legitimadora (efeito da competição por capitais e da substituição do processo político de decisão pela dinâmica do mercado) (HABERMAS, 1999, p. 38-39).7

Atentos às insuficiências notadamente geradas ao longo da história dos direitos humanos, todos os que se preocupam com a política e o direito buscam discutir aqueles sob a orientação de um novo paradigma, voltado para a superação de um modelo positivista que, ao longo da história, se mostrou insuficiente. Esse novo paradigma não abre mão da presença do Estado, ainda como a mais importante das instituições modernas, todavia reconhece a necessidade de uma revisão dos pressupostos intersubjetivos de convivência sustentável, quais sejam: uma interação equânime entre Estado, democracia e diretos humanos.

Eis aí, então, a necessidade de se (re)inserir a discussão ética no Direito, pois essa discussão, assim chamada em virtude de estar vinculada à concepção da democracia como regime político que se fundamenta em valores morais da pessoa humana, permite que se incorpore à interpretação da lei no caso concreto as finalidades do regime democrático. O sentido da leitura do Direito, em especial 
no que tange à aplicação de direitos humanos, torna-se ética na medida em que valores, como liberdade, igualdade e fraternidade, são encarados não como simples arranjos político-institucionais, mas sim como dimensões morais do cidadão a serem implementadas na sociedade política (BARRETO, 2004).

\section{OS DIREITOS FUNDAMENTAIS E A DEMOCRACIA COMO PILARES DA CONSTITUIÇÃO DIRIGENTE}

Para a implementação de um discurso eficientemente democrático, Claude Lefort parece ter ofertado importante pista para uma adequada visão dos direitos humanos em tempos de crise do Estado e do Direito Moderno. Em sua obra na qual intenta dialogar com aqueles que desferiram duras críticas aos direitos humanos - tachando-os de artifícios, que servem como verdadeiro "véu" utilizado para "mascarar as relações estabelecidas nas sociedades burguesas" -, como foi o caso, em especial, de Karl Marx (2002), Lefort (1991, p. 50) defende a idéia de que “[...] os direitos do homem não são um véu, [pois] longe de terem por função mascarar a dissolução dos liames sociais - fazendo de cada um, uma mônada -, os direitos do homem atestam e, ao mesmo tempo, suscitam uma nova rede de relações entre os homens" (LEFORT, 1991, p. 50).

Assim, para sustentar essa rede de relações, deve-se buscar, num viés democrático original, um duplo fenômeno que acompanha as diversas declarações de direitos humanos, quais sejam:

[...] (a) um poder destinado doravante a permanecer em busca de seu fundamento, porque a lei e o saber não são mais incorporados na pessoa daquele ou daqueles que o exercem, e (b) uma sociedade acolhendo o conflito de opiniões e o debate dos direitos, porque se dissolveram os marcos de referência da certeza que permitiam aos homens situaremse de uma maneia determinada, uns em relação aos outros (LEFORT, 1991, p. 52).

O raciocínio moderno, portanto, da soberania que opunha Estado e sociedade civil, não pode ser desenvolvido mais hegemonicamente, principalmente em relação aos direitos humanos, pois, diante da complexidade que envolve o aparelho de Estado, percebe-se, 
quotidianamente, o quanto este é impotente para garantir as políticas internas de implementação e garantia dos direitos fundamentais, bem como também é insuficiente para a defesa dos direitos humanos em face do choque provocado pela globalização neoliberal.

Em síntese, ainda com Lefort, entende-se que "[...] assim como o Estado não pode fechar-se em si mesmo para tornar-se o grande órgão que comanda todos os movimentos do corpo social, assim também os detentores da autoridade política permanecem obrigados a repor em causa o princípio de conduta dos assuntos públicos" (LEFORT, 1991, p. 54).

Isso reforça a própria idéia lefortiana de que se deve, constantemente, reinventar e atualizar a democracia, porque esta, como afirma Chaú, "[...] trata da criação ininterrupta de direitos, da subversão contínua de estabelecidos, da reinstituição permanente do social e do político". ${ }^{8}$

Essa assertiva, que traz o viés politizador do Direito,

[...] ultrapassa não só o sentido conservador do liberalismo que reduz os direitos humanos ao seu caráter de direito natural, vistos como questão puramente ética, como também as críticas marxistas que reduzem o ideário democrático à pura ideologia. Para o marxismo, a democracia não possui força política, sendo no máximo uma relação de forças. $\mathrm{Na}$ verdade, a democracia é uma forma política articulada a partir do princípio da enunciação de direitos, onde o princípio maior é o direito de enunciá-los (ROCHA, 2003, p. 180).

Não se pode deixar de registrar o cenário (acelerado) globalizante, que obriga a reflexão acerca da necessidade de que

[...] percebamos que o espaço da democracia, em razão de um processo conjunto de desterritorialização e reterritorialização consectário da complexidade das relações contemporâneas, se multiplica, não ficando mais restrito aos limites geográficos do Estado Nação, mas incluindo o espaço internacional, comunitário, além das experiências locais - como, e.g., no caso dos projetos de democracia participativa (MORAIS, 2001, p. 71, grifo do autor).

Essa temática - que envolve a atuação do Estado em prol dos Direitos Humanos sob o impacto da globalização neoliberal - será 
retomada mais à frente, onde analisar-se-á tal atuação a partir de uma postura constitucional-dirigente. Por hora, é válido registrar a relação existente entre os direitos fundamentais e a democracia como pressupostos para a implementação do projeto constitucional de 1988.

Analisando-se o movimento de redemocratização do Estado brasileiro, iniciado na década de 1980, percebe-se que o intuito daqueles que se reuniram no movimento constituinte não foi apenas o de participar do processo de reconstrução do Estado de Direito, após anos de autoritarismo militar, mas também - em oposição ao positivismo e revelando um compromisso com os ideais do pensamento comunitário - dar um fundamento ético à nova ordem constitucional brasileira, tomando-a como estrutura normativa que incorpora os valores de uma comunidade histórica concreta. Nessa perspectiva, "[...] os representantes deste constitucionalismo 'comunitário' se contrapõem à idéia de que a tarefa primordial da Constituição é a defesa da autonomia dos indivíduos (e da sociedade) contra um poder público inimigo, por meio da criação de um sistema fechado de garantias da vida privada" (CITTADINO, 2004, p.01).

A atuação decisiva dos constitucionalistas "comunitários" no processo constituinte dos anos 80 foi fundamental para a incorporação, por parte da Constituição de 1988, de todos esses compromissos, podendo-se enumerar várias "marcas comunitárias" no ordenamento constitucional:

[...] em seu preâmbulo, quando identifica a igualdade e a justiça como valores supremos da sociedade brasileira; ao definir os objetivos e fundamentos do Estado Brasileiro, destacando a dignidade da pessoa humana e a construção de uma sociedade justa e solidária; ao adotar diversos institutos processuais que asseguram o alargamento do círculo de intérpretes da Constituição, revelando um compromisso com a soberania popular e com a democracia participativa; e finalmente quando confere ao Supremo Tribunal Federal atribuições jurídicopolíticas de uma Corte Constitucional (CITTADINO, 2004, p. 228).

É importante notar que o traço marcante do comunitarismo identificado na postura assumida pela Constituição de 1988, qual seja, a equiparação de princípios e normas constitucionais a valores, não encontra inspiração em um movimento ou em uma teoria específica, mas em diversas concepções de comunitaristas. 
A noção de Estado, portanto, é acoplada ao conteúdo material das constituições, mediante seus valores substantivos compartilhados historicamente, numa tradição, pois a teoria dos direitos humanos

[...] não proíbe de maneira alguma que os cidadãos do Estado Democrático de Direito, no âmbito de uma ordem estatal conjunta, validem uma concepção do que seja bom, advenha ela da própria origem cultural, ou de um consenso alcançado em discursos de natureza política; entretanto, essa mesma teoria proíbe sim, no interior do Estado, que se privilegie uma forma de vida em detrimento de outra (HABERMAS, 2002, p. 229).

E parece que, mesmo estando definidos democraticamente, os valores - dentre eles, o mais importante que é a dignidade humana', - e suas prioridades na Constituição, as possibilidades que são constantemente abertas para a aplicação (aplicatio, no sentido empregado por Gadamer (1994)) do Direito exigem do jurista, em especial do juiz, a devida postura hermenêutica em cada caso concreto. Por isso, no Estado Democrático de Direito, a lei (Constituição) passa a ser uma forma privilegiada de instrumentalizar a ação do Estado na busca do desiderato apontado pelo texto constitucional, entendido no seu todo dirigente-valorativo-principiológico. ${ }^{10}$

Nessa perspectiva, Siqueira Castro, inspirado nas obras de comunitaristas, como Walzer ${ }^{11}$ e Taylor, ${ }^{12}$ edificou a sua tese acerca do constitucionalismo societário e comunitário, que toma a Constituição como uma estrutura normativa que envolve um conjunto de valores. Donde se verifica, portanto, a conexão entre os valores "[...] compartilhados por uma determinada comunidade política e a ordenação jurídica fundamental e suprema representada pela Constituição, cujo sentido jurídico, conseqüentemente, só pode ser apreciado em relação à totalidade da vida coletiva" (CASTRO, 2005, p. 21).

Assim, a Constituição de 1988, inserida num momento histórico brasileiro, surge como uma Constituição-compromisso, pois, “[...] além de descortinar um roteiro extensivo para o atingimento das renovadas metas sociais-democráticas, sua missão mais notória foi, sem dúvida, a de coroar e dar fecho ao processo de transição lenta e gradual projetado pelos arquitetos do declínio da ditadura militar."13

Em suma, as preocupações do texto constitucional assentam- 
se em dois princípios basilares que são a proteção e efetivação dos direitos humanos e a sedimentação da democracia. O primeiro inspirado no movimento protetivo iniciado, principalmente, no âmbito internacional, após a II Guerra, com a Carta da ONU de 1948, juntamente com os demais tratados internacionais de direitos humanos que a sucederam, e, no plano intra-estatal, com as Constituições garantidoras do século XX. Ambos os princípios como respostas ao Estado autoritário militar brasileiro e à ausência de reconhecimento e respeito ético-culturais.

\section{O CONSTITUCIONALISMO DIRIGENTE E A BUSCA DAS PROMESSAS DESCUMPRIDAS}

Como uma típica Carta-compromissária, a atual Constituição encarnou a síntese das contradições brasileiras juntamente com o desejo de mudança. Da mescla ideológica do Poder Constituinte (BONAVIDES, 1989), traduz-se o embate entre as diversas forças que compuseram a Assembléia Nacional (1986-88). Com inspiração em postulados humanistas, em que radicam a efetivação de direitos sociais e a sedimentação da democracia, a Constituição reúne

[...] um magnânime e humanitário projeto de pacificação nacional ao lado de um elenco de direitos à esperança, a serem efetivados segundo a capacidade transformadora da sociedade e da classe política brasileira, do que propriamente uma solução acabada de organização social e política para um país marcado por impenitentes contrastes classistas e regionais (CASTRO, 2005, p. 125).

Os compromissos assumidos pela Constituição brasileira de 1988 - especialmente aqueles previstos em seus três primeiros artigos fazem com que esta seja classificada, segundo a sua estruturação, como Constituição Dirigente, por não se resumir a um mero ordenamento político, mas também como ordenamento econômico e social. A tese do Constitucionalismo Dirigente foi amplamente divulgada no Brasil a partir da obra de J. J. Gomes Canotilho (2001) - inspirada inicialmente em diferentes obras, como a de Vezio Crisafulli e Peter Lerche $^{14}$-, que, tendo como enfoque privilegiado a Constituição portuguesa de 1976, buscava afastar de vez qualquer dúvida em 
relação à aplicabilidade das normas programáticas. Nessa visão, em síntese, desvaloriza-se a idéia clássica de Constituição como estatuto delimitador do Poder, para que se confira um grande valor às normas programáticas e aos objetivos de mudança econômica e social que, na ótica da Constituição portuguesa, visariam à transição gradativa para o socialismo (era o que dispunha o art. $1^{\circ}$, atualmente revogado, da Constituição portuguesa de 1976).

O modelo de Constituição Dirigente inspirou diversos membros da Assembléia Constituinte brasileira. Por isso, a presente Constituição não almeja simplesmente retratar a realidade política vigente, como em modelos ultrapassados do século XX, mas também cuida da inserção de objetivos programáticos que não poderiam ser aplicados no momento da elaboração do texto constitucional. Em simples termos, os agentes do Poder Constituinte originário submetem os futuros governos e a sociedade à realização de princípios constitucionalmente aventados para a transformação da realidade social. Assim, nas palavras de Canotilho (2001, p. 487), o “[...] programa constitucional de governo concebe-se também como programa em conformidade com a Constituição, devendo distinguir-se de outras figuras afins com as quais anda sistematicamente confundido (programa eleitoral e partidário, acordo partidário-governamental e acordo programáticogovernamental)."

Canotilho, com isso, propõe "[...] a reconstrução da teoria da Constituição por meio de uma Teoria Material da Constituição, concebida também como teoria social. A Constituição Dirigente busca racionalizar a política, incorporando uma dimensão materialmente legitimadora, ao estabelecer um fundamento constitucional para a política" (BERCOVICI, 2006, p. 243).

É interessante registrar que a publicação de um artigo numa revista espanhola, em 1995, acerca do dirigismo constitucional, causou um enorme frisson em todos aqueles que se preocupavam com a efetivação do texto constitucional, tendo em vista que o próprio Canotilho, "pai" de tal teoria, teria decretado a morte da Constituição Dirigente $^{15}$. Todavia o próprio autor encarregou-se de acalmar os nervos dos (neo)constucionalistas brasileiros, ao afirmar que "[...] a Constituição dirigente está morta se o dirigismo constitucional for entendido como normativismo constitucional revolucionário capaz 
de, só por si, operar transformações emancipatórias"(CANOTILHO, 2001, p. XXIX). Assim, após, inclusive, as discussões entre juristas brasileiros e o próprio Canotilho no seminário intitulado "Jornadas sobre a Constituição Dirigente em Canotilho", perceberam-se que a morte apresentada pelo autor era relativa, pois tal teoria não teria falecido e sim amadurecido, emancipado e alcançado novos horizontes significativos (GRAU, 2005).

A partir disso, Streck (2004, p. 301, grifo do autor) afirma que

[...] para uma melhor compreensão da problemática relacionada à sobrevivência ou morte da assim denominada Constituição dirigente, é necessário que se entenda a Teoria da Constituição enquanto uma teoria que resguarde as especificidades histórico-factuais de cada Estado nacional. Desse modo, a teoria da Constituição deve conter um núcleo (básico) que albergue as conquistas civilizatórias próprias do Estado Democrático (e Social) de Direito, assentado, como já se viu à sociedade, no binômio democracia e direitos-fundamentais-sociais. Esse núcleo derivado do Estado Democrático de Direito faz parte, hoje, de um núcleo básico geral-universal que comporta elementos que poderiam confortar uma teoria geral da Constituição e do constitucionalismo do Ocidente. Já os demais substratos constitucionais aptos a conformar uma teoria da Constituição derivam das especificidades regionais e da identidade nacional de cada Estado.

Com essa concepção, alcança-se a convicção de que a Constituição não pode ser entendida como entidade normativa independente e autônoma, sem história e temporalidade próprias. Não há uma teoria da Constituição, mas várias teorias da Constituição, adequadas à realidade concreta. A Constituição não deve estar apenas adequada ao tempo, mas também a ao espaço. Afora o núcleo universal, capaz de ensejar "a" teoria geral da Constituição, "há um núcleo específico" que se amolda historicamente e espelha anseios variados em diversos Estados - e se pode chamar de núcleo de direitos social-fundamentais plasmados em cada texto que atendam ao cumprimento das promessas da modernidade. Assim,

O preenchimento do déficit resultante do histórico descumprimento das promessas da modernidade pode ser considerado, no plano da Constituição adequada a países periféricos ou, mais especificamente, de uma Teoria da Constituição Dirigente Adequada aos Países de Modernidade 
Tardia (TCDAPMT), como conteúdo compromissário mínimo a constar no texto constitucional, bem como os correspondentes mecanismos de acesso à jurisdição constitucional e de participação democrática.

Uma Teoria da Constituição Dirigente Adequada a Países de Modernidade tardia, que também pode ser entendida como uma teoria da Constituição dirigente-compromissária adequada a países periféricos, deve, assim, cuidar da construção das condições de possibilidade para o resgate das promessas da modernidade incumpridas, as quais, como se sabe, colocam em xeque os dois pilares que sustentam o próprio Estado Democrático de Direito (STRECK, 2004, p. 332). ${ }^{16}$

Todavia a implementação das promessas da modernidade, por meio de um Estado Democrático de Direito, interage com outros fatores complicadores. Dentre estes, destaca-se o fenômeno recente, das últimas décadas, cuja análise se torna inafastável quando o assunto é atuação estatal e efetivação de direitos. Trata-se da globalização neoliberal que impactou e segue impactando o Estado na modernidade, impedindo, inclusive, a efetivação de direitos sociais, prejudicando, conseqüentemente, o outro pilar do Estado Democrático de Direito, que é a democracia.

Considerando-se que a legitimidade e a atuação do Estado na modernidade se pautam pela noção de soberania, entendida como um ponto de referência necessário para as teorias políticas e jurídicas, cuja finalidade básica é justificar o monopólio da força num determinado território e sobre uma determinada população, com a globalização, especialmente em suas facetas econômica e tecnológica, aduz Bauman, citando Paul Virilio, que a soberania territorial perdeu quase toda a substância e boa parte de sua atração, pois, na medida em que cada ponto pode ser alcançado e abandonado no mesmo instante, a posse permanente de um território, com seus deveres e compromissos de longo prazo, transforma-se em um passivo e se torna um peso e não mais um recurso na luta pelo poder (BAUMAN, 2003).

Assim, pode-se afirmar que a união entre a Nação e o Estado, sustentáculo fundante da soberania, não pode ser mais vista como um conceito sólido. Talvez, Bauman (2003, p. 212) esteja com a razão, quando afirma: 
O romance secular da nação com o Estado está chegando ao fim; não exatamente um divórcio, mas um arranjo de 'viver juntos' está substituindo a consagrada união conjugal fundada na lealdade incondicional. Os parceiros estão agora livres para procurar e entrar em outras alianças; sua parceria não é mais o padrão obrigatório de uma conduta própria e aceitável. [...] Parece haver pouca esperança de resgatar os serviços de certeza, segurança e garantias do Estado. A liberdade da política do Estado é incansavelmente erodida pelos novos poderes globais providos das terríveis armas da extraterritorialidade, velocidade de movimento e capacidade de evasão e fuga (BAUMAN, 2003, p. 100).

'A economia' - o capital, que significa dinheiro e outros recursos necessários para fazer as coisas, para fazer dinheiro e mais coisas move-se rápido; rápido o bastante para se manter permanentemente um passo adiante de qualquer Estado (territorial, como sempre) que possa tentar conter e redirecionar suas viagens [...] A 'globalização' nada mais é que a extensão totalitária de sua lógica a todos os aspectos da vida. Os Estados não têm recursos suficientes nem liberdade de manobra para suportar a pressão - pela simples razão de que 'alguns minutos bastam para que empresas e até Estados entrem em colapso' (BAUMAN, 1999, p. 63 e 73).

Com essas afirmações apresentadas, não se quer induzir a conclusão de que o Estado-Nação não desempenhe mais funções relevantes na nova ordem internacional, nem que a soberania estatal, na sua face voltada para o plano interno, tenha deixado de existir, mas o que, seguramente, se pode afirmar é que o modelo tradicional apresentado a partir do século XVI sofreu impactos altamente contundentes e deformadores em seu percurso histórico, em especial, a partir da segunda metade do século XX. Em outras palavras, resume-se a crise como um fenômeno que não pode ser ignorado, mas que, ao mesmo tempo, não faz desaparecer o poder e, sim, uma determinada forma de organização do poder, que teve seu ponto de força no conceito político-jurídico de soberania (MATTEUCCI, 2000).

O Estado-providência (assistencial), com sua promessa de equilíbrio entre a liberdade e a igualdade, entrou em crise. Como diagnóstica Ost (1999, p. 337),

[...] a sociedade assistencial desagrega-se, a ciência e a lei são atingidas pela dúvida, o mercado e a privatização triunfam, ao mesmo tempo que 
o medo regressa. A 'sociedade do risco' toma então o lugar do Estadoprovidência, e volta-se a falar de segurança em vez de solidariedade. É que o risco assume um outro rosto e uma outra escala, iludindo os instrumentos clássicos de prevenção.

O modelo de sociedade solidária, que deveria interagir com o Estado-providência, para que este pudesse cumprir com as suas promessas, não se sustentou (ou, na verdade, sequer foi implementado) na modernidade ocidental. ${ }^{17}$ Vale agora a lógica de uma sociedade individualista e, paradoxalmente, globalizada. De acordo com Rocha (2004, p. 45),

A transnacionalização é a união de dois pólos espaciais inconciliáveis na lógica tradicional: o local e o universal. Para muitos, pareceria a recuperação da dialética, porémnão setrata da possibilidade denenhuma síntese. Trata-se da produção da simultaneidade entre a presença e a ausência que somente é possível devido a sua impossibilidade. Este paradoxo é constitutivo da nova forma de sociedade que começamos a experimentar, e, nesse sentido, é um convite a reinventar, uma vez mais, o político e o Direito.

Quando se ingressa numa sociedade globalizada (transnacionalizada ou pós-moderna), “[...] o problema é o fato que qualquer perspectiva mais racionalista ligada ao normativismo e ao Estado se torna extremamente limitada. Não se pode assim continuar mantendo uma noção de racionalidade no Direito ao se insistir no ideal kelseniano" (ROCHA, 2001, p. 117).

A perspectiva normativista, delineada nos itens anteriores, engessa as possibilidades de decisão numa sociedade extremamente complexa, marcada pela incerteza e pela ausência de definições absolutas. O problema do Direito, conforme esclarece Rocha, "[...] é que ele é uma estratégia de imposição de certos valores consagrados que se quer que se repitam empiricamente em situações semelhantes no futuro" (ROCHA, 2001, p. 130). A dogmática jurídica, como esse arcabouço teórico construído desde o passado, tem a pretensão de alcançar soluções para todos os conflitos a partir da institucionalização de valores.

O Direito possui sua existência vinculada ao tempo, estando ambos relacionados com a sociedade. O problema está na falta de 
sincronia entre o tempo do Direito estatista em face dos acontecimentos de uma sociedade globalizada. O paradigma jurídico moderno não é capaz de atender às inúmeras contingências dessa forma de sociedade.

Porém, “[...] o Estado ainda detém o monopólio em muitas questões-chave da sociedade, dificultando as análises simplistas que afirmam o seu desaparecimento. $\mathrm{O}$ Estado continua existindo, ao lado de outras organizações, caracterizando mais um paradoxo, é soberano e não-soberano" (ROCHA, 2004, p. 46).

Como consectário da crise da soberania estatal, na contemporaneidade - associada às crises estrutural, funcional e política (MORAIS, 2002, p. 40) que vêm induzindo aos “[...] desmontes de Estados"18 -, aparece a crise constitucional, que se manifesta por meio do chamado processo de desconstiotucionalização promovido pelo dito neoliberalismo. ${ }^{19}$ Nesse sentido, a Constituição - considerada o locus privilegiado na modernidade, onde, num primeiro momento, se instalaram conteúdos de um Estado burocrático e de um sistema que, apertadamente, definiu o perfil do poder soberano e assegurou os direitos individuais, transformando-se, posteriormente, num terreno de intermediação e negociação entre interesses e valores conflitantes (tendo como resultado mais sintomático o reconhecimento de valores socioeconômicos) - aparece, neste fim de século XX e início de século XXI, como um verdadeiro entrave para o funcionamento do mercado, como um freio da competitividade dos agentes econômicos e como obstáculo da expansão da economia (SANTOS, 2002).

Em face desse paradoxal cenário de crises insuficiências, no qual o Estado (ainda) sobrevive, qual seria, então, a função da Constituiçãodirigente-compromissária?

\section{CONSTITUIÇÃO, ESTADO E O IMPACTO DA GLOBALIZAÇÃO NEOLIBERAL}

A construção hermenêutica de um sentimento constitucional pode ser o elo entre a situação de indignidade humana e o estágio social mais justo conforme prometido pelo art. $3^{\circ}$ da Constituição brasileira. Para tanto, a atuação do Estado, ao contrário da teoria defendida pelo discurso neoliberal, se faz fundamental. A Constituição de 1988, com o seu texto dirigente-compromissário, intenta implementar um 
modelo de Estado que venha, finalmente, atender aos seus fins sociais, historicamente (so)negados.

Nesse sentido, a construção da cidadania no Brasil faz-se necessária para que seja possível a implementação da Constituição. Por isso, a importação, no campo jurídico-político, de modelos procedimentais, como o de Habermas, precisa ser lidos com ressalvas e com as necessárias adaptações, pois a leitura procedimentalista do Direito e, conseqüentemente, da Constituição, pressupõe um estágio social mínimo, verificado em nações centrais européias e na norteamericana. ${ }^{20}$

Sobre essa temática, a concepção procedimentalista habermasiana pode ser resumida na "[...] conexão entre imparcialidade do Estado de Direito ou indisponibilidade do direito, por um lado, e a sua instrumentalidade sistêmica, por outro" (NEVES, 2006, p. 246). Todavia, a impossibilidade de se adotar uma postura eminentemente procedimental em relação à Constituição ocorre porque a "[...] experiência brasileira marca-se por formas de instrumentalização política, econômica e relacional de mecanismos jurídicos, apontando no sentido inverso à indisponibilidade do direito" (NEVES, 2006, p. 246). Isso porque, na modernidade periférica pátria:

Pode-se afirmar que, conforme o modelo textual das Constituições de 1824, 1891, 1934, 1946 e 1988, teria havido um inquestionável desenvolvimento do Estado de Direito no Brasil, que não se distinguiria basicamente dos seus congêneres na Europa Ocidental e na América do Norte. No entanto, no plano da concretização, não se observou um correspondente desenvolvimento: o Estado permanece sendo amplamente bloqueado pela sociedade envolvente, e Têmis, freqüente e impunemente 'violada' por Leviatã.

Nesse contexto de instrumentalização do direito sem o contrapeso da sua indisponibilidade, há restrições complexas à 'autonomia privada' e à 'autonomia pública' no sentido habermasiano, ou seja, não se desenvolvem, respectivamente, os direitos humanos e a soberania do povo. A primeira implica a liberdade igual dos cidadãos. A segunda, procedimentos de formação da vontade estatal abertos imparcialmente à esfera pública pluralista. No Brasil, por um lado, a 'autonomia privada' é profundamente prejudicada pelas relações de dependência que se estabelecem entre privilegiados e 'excluídos'. Na medida em que os direitos humanos constitucionalmente estabelecidos como fundamentais não se concretizam, fortifica-se o significado dos favores e do clientelismo. Com 
esse problema relaciona-se a fragilidade dos procedimentos constitucionais democráticos, em torno dos quais se estruturaria uma esfera pública pluralista, verifica-se uma tendência à privatização do Estado (NEVES, 2006, p. 245, grifo nosso).

A situação, portanto, é mais grave na medida em que se diagnostica, concomitantemente à formação da desigualdade no Brasil, a ausência de um Estado de Direito no sentido da sua impessoalidade. O princípio da legalidade valia (e vale!) não para todos (para os amigos tudo, para os inimigos a lei!). Nesse caso, não se trata de uma referência “[...] às experiências autoritárias de 1937-45 e 1964-84, [quando houve] uma negação direta e expressa do estado de Direito, estando a subordinação de Têmis a Leviatã prescrita claramente nas próprias leis constitucionais" (NEVES, 2006, p. 244).

Assim, entende-se que

[...] o fetichismo da lei no Brasil é unilateralista, funciona como mecanismo de discriminação social. Dirige-se, normalmente, aos subintegrados. A interpretação legalista é normalmente aplicada àqueles que não se encontram em condições de exercer os seus direitos, mesmo que estes sejam 'garantidos' legal e constitucionalmente. Trata-se de falta de acesso ao direito e, por conseguinte, de 'exclusão' social. Em regras, as respectivas pessoas e os grupos sociais correspondentes só são considerados pelo legalismo unilateral quando entram em contato com o sistema a seu desfavor, ou seja, como culpados, réus, condenados, presos etc., não como detentores de direitos. A respeito, pois, tem sentido realmente falar em subintegração no sistema jurídico.

Os indivíduos estão subordinados rigorosamente às prescrições coativas, mas não têm acesso aos direitos. A rigidez legalista, parcial e discriminatória, contraria a própria legalidade, que implica a generalização de conteúdos e procedimentos da ordem jurídica em termos isonômicos (NEVES, 2006, p. 254-255).

Se, por um lado, a crise da legalidade, descrita acima por Neves, integra o triste drama da subcidadania social, com a subintegração no sistema jurídico, por outro, conforme visto alhures, a perda de eticidade no Direito é reflexo da perda de eticidade das sociedades pós-convencionais, cujo principal efeito é o fato de que o mundo da vida tem sido "colonizado" mediante processos de "monetarização" e "burocratização". O dinheiro e o poder constituem meios de controle que são independentes da linguagem que o geram, portanto, 
estruturas sociais isentas de conteúdo normativo ou prático-moral (CITTADINO, 2004).

Com o esvaziamento da discussão ética da decisão jurídica (e do próprio Direito), "a ciência jurídica" segue tentando conciliar interesses liberais-individuais com a "ética" do mercado. Essa parece ser, inclusive, a lógica do Tribunal Constitucional brasileiro, conforme afirmou seu ex-Presidente Nelson Jobin: "[...] o Judiciário, no trânsito democrático, precisa ter três coisas para ser confiável: previsibilidade, decisão em tempo social e econômico tolerável e acessibilidade" (JOBIN, 2004, p. 38)

Não se trata de negar a velocidade das transformações globais e nem as novas demandas propostas em face disso, mas o problema aparece quando se assume que a nova religião, que antes fora a ciência, agora é o mercado.

Diante disso, o dirigismo constitucional contribui com seu arcabouço legal, do qual podem se valer os seus intérpretes na defesa dos interesses humanos em face da avalanche mercadológica ( $O$ mercado é a lei), propagada pela nova forma que assumiu o processo de globalização. Esse processo, marcado basicamente pelo "mercado livre" passou a ser a marca característica do neocapitalismo, que só se instalou "[...] definitivamente após o desmoronamento da URSS em 1991, apesar de sua origem estar, em 1944, com Hayek, que visava atingir o Partido Trabalhista da Inglaterra, vez que haveria eleições em 1945" (MELLO, 2000, p. 804). Há aproximadamente um quarto de século anos, com a propagação da doutrina neoliberal na Inglaterra (ascensão ao cargo de Primeiro Ministro de Margaret Thatcher, em 1979) e nos Estado Unidos (eleição de Ronald Reagan à Presidência, em 1980), a proposta de retorno a uma espécie de Estado mínimo é difundida, e a liberdade volta a ser o grande princípio das relações dos Estados entre si e destes com os indivíduos.

Entretanto, com Mello (2004, p. 804-805), pode-se afirmar que

[...] o neoliberalismo se esquece que só há liberdade quando não existe miséria [...]. A liberdade tem sido um luxo para uma pequena minoria e o mesmo tem ocorrido no plano internacional. Não se pode defender igualdade de pessoas ou Estados que têm condições de partida diferentes para a maratona de sua existência. O livre mercado é 
benefício para os Estados poderosos nas relações internacionais e para os ricos no âmbito interno dos Estados [...]. O livre mercado só visa ao lucro e o aspecto social é abandonado.

No atual estágio civilizatório, fortemente impactado por “[...] movimentação axiológica das sociedades de massa e pelo processo de urbanização e globalização planetária, tudo associado às impressionantes tecnologias das comunicações, o sobrevivente modelo constitucional do Estado nacional" (CASTRO, 2005, p. 23), deve ser interpretado numa perspectiva hermenêutica que se coaduna com a visão de Vieira de Andrade (2004, p. 80), que defende que a visão dualista que contrapõe o indivíduo e a sociedade ao poder público ("inimigo")

[...] corresponderia a uma visão liberal do indivíduo, da sociedade e do Estado, e não seria hoje defensável, dado que não tomava em conta o alargamento da esfera política, a interpenetração entre Estado e a sociedade e a integração dos indivíduos no processo político comunitário, que conferem aos direitos fundamentais uma dimensão objetiva, enquanto elementos da democracia ou instrumentos para a construção de uma sociedade mais justa e livre.

Essa ideologia liberal burguesa não se coaduna com projeto constitucional de construção de uma "comunidade republicana", que "[...] é incompatível com as separações criadas pelo capitalismo na sociedade moderna: a separação entre o Estado e a sociedade civil, ou entre a esfera econômica e social" (COMPARATO, 2006, p. 620).

O sucesso histórico da superação do positivismo pelo póspositivismo, com o triunfo das Constituições sobre os Códigos (Bonavides), donde se extrai a sua normatividade que, por sua vez, não pode significar a opção pelo cumprimento ad hoc de dispositivos "menos significativos" da Lei Maior e o descumprimento sistemático daquilo que é mais importante - seu núcleo essência fundamental -, depende da atuação da jurisdição constitucional. A compreensão desse novo paradigma jurídicopolítico, segundo Streck (2004), será essencial para a efetivação dos direitos previstos nos textos constitucionais. Nesse contexto, dogmas edificados desde o surgimento do Estado Liberal, tais como "[...] soberania popular, separação de poderes e maiorias parlamentarias 
vão dar lugar à discussão acerca da legitimidade constitucional, instituidora de um constituir da sociedade" ${ }^{21}$

Esta transferência de enfoque - dos dogmas liberais modernos para a atuação da Jurisdição Cosntitucional - não implica o abandono do poder do Estado e sim um redimensionamento de seus conceitos, dentre os quais, em especial, o de soberania que, conforme visto, deve ser revista inclusive à luz dos fortes abalos sofridos em face da globalização neoliberal.

Nesse sentido, os dogmas que regem o conceito de soberania devem ser superados, o que não implica dizer que a própria soberania será superada, mas, sim, remodelada, ou seja, adequada às transformações espaciais dos direitos humanos em período de transformações do Estado e do próprio direito.

É interessante notar que, enquanto governos e juristas se apóiam em discursos inflexíveis em defesa da soberania, assistese, diariamente, ao esfacelamento da "barreira soberana" pela globalização econômica. Rendendo-se às pressões geradas pelo movimento de globalização, os Estados, ao longo dos anos, acabaram por suprimir uma série de direitos fundamentais de seus cidadãos. Todavia tal registro se perfaz num paradoxo porque esse próprio movimento opressivo acaba gerando uma reação contrária, qual seja, a busca pela afirmação dos direitos humanos, que, por sua vez, depende dos Estados.

Corroborando essa constatação, Faria (2004, p. 12-13) aduz que

[...] se no plano jurídico os processos de desregulação, deslegalização e desconstitucionalização promovidos pelos governos nacionais ao longo das duas ou três últimas décadas, para se adaptar às exigências de um mundo globalizado, revogaram importantes conquistas históricas, em matéria de direitos humanos, no plano político sub ou supranacional e nas esferas não-estatais eles continuarão sendo um importante critério para animar, orientar e fundamentar lutas em favor da revitalização da dignidade humana e das diferentes formas de liberdade.

Portanto as teorias acerca da soberania devem se adequar ao novo contexto global e essa transformação deve ser acompanhada da concepção acerca do conceito de cidadania que, por sua vez, conforme visto, está intimamente ligada àquela. 


\section{CIDADANIA E CONSTITUIÇÃO DIRIGENTE}

Se a democracia foi sintetizada como a possibilidade de se enunciar direitos, numa perspectiva garantidora da constante atualização dos direitos humanos, a cidadania, agora, na visão arendtiana, deve ser celebrada, na perspectiva democrática, como o direito a ter direitos (LAFER, 2003), máxima alcançada após detida preocupação com a questão dos apátridas, mas que acabou contribuindo para uma revisão político-jurídico-filosófica dos direitos humanos, bem como para o rompimento com a noção estrita de cidadania.

As implicações jusfilosóficas da concepção da cidadania como direito a ter direitos, captada por Lafer, em sua obra, extrapolam os incidentes totalitários que chocaram a humanidade no século XX, com destaque para o nazismo, e alcançam o ponto de vista sobre os direitos humanos que se relacionam com a cidadania, considerandose a igualdade e a diferença como paradoxo indissociável da existência humana. As pessoas necessitam da diferença para se afirmarem em suas esferas privadas e, ao mesmo tempo, encontram a igualdade na participação política desde a polis até o Estado Nação (ARENDT, 2004).

Todavia a participação política e o reconhecimento do indivíduo como cidadão que tem direito não podem ser atrelados apenas ao Estado Nação, segundo a teoria da internacionalização da defesa dos direitos humanos. ${ }^{22}$ Se as transformações impactaram o Estado, que não se afirma mais soberanamente, na perspectiva moderna, e se a preocupação com os direitos humanos expandiu-se para além das fronteiras territoriais, principalmente a partir de 1948, o conceito de cidadania também pode ser revisitado,

[...] não apenas em seus conteúdos - mas, e particularmente, em seus espaços de expressão, embora hoje prevaleça, ainda, uma noção de cidadania identificada com um elenco conhecido de liberdades civis e políticas, assim como de instituições e comportamentos políticos altamente padronizados, que possibilitam a participação formal dos membros de uma comunidade política nacional, especialmente na escolha de autoridades que ocupam os mais elevados cargos e funções de governo, estando, também ela, indissociável da idéia moderna de território (GOMES, 2000, p. 90). ${ }^{23}$ 
Os direitos fundamentais são um repertório comum que a comunidade, não mais apenas nacional, mas global, compartilha simbolicamente, seja como transformação de situações aviltantes à dignidade humana, seja como mecanismos de contestação (e resistência) em face dos efeitos negativos provocados pelo fenômeno da globalização. Se o direito a ter direitos significa "[...] pertencer, pelo vínculo da cidadania, a algum tipo de comunidade juridicamente organizada e viver numa estrutura onde se é julgado por ações e opiniões [...]" (LAFER, 2003, p. 154), e se a comunidade juridicamente organizada passou (e continua passando) por transformações, logo a noção de cidadania deve ser pensada para além da soberania nacional.

Em virtude disso, ao atualizar a noção acerca da cidadania, as palavras de Lafer, na trilha de pensamento de Arendt, servem para sintetizar a presente exposição, na medida em que afirma que,

Num mundo único a cidadania, como base para o direito a ter direitos e como condição para o indivíduo beneficiar-se do princípio da legalidade, evidenciando-se dessa maneira o surgimento de um novo 'estado totalitário de natureza', não pode ser examinada apenas no âmbito interno de uma comunidade política. Em verdade, só pode ser assegurada por um acordo da comitas gentium, pois este só pode existir, observa Hannnah Arendt em artigo publicado em 1949, por meio de acordo e garantias mútuas, pois não se trata de algo dado, mas construído, e este construído, no caso, requer um entendimento de alcance internacional. A relevância desta conclusão não é hoje contestada em Direito Internacional Público, que ratione materiae necessariamente inclui no seu objeto a repartição legal da população mundial (LAFER, 2003, p. 154)

Assim, reconhece-se, hodiernamente, cada vez mais a implementação da defesa dos direitos humanos para além das fronteiras estatais, numa tentativa deconstrução deum sistemaintegrado internacional de proteção dos direitos humanos, formado essencialmente pela interseção normativa entre tratados internacionais e textos constitucionais. E o ponto central desse sistema consiste justamente na idéia de dignidade humana, capaz de gerar

[...] novas pautas hermenêuticas para a interpretação da realidade social, econômica, política e cultural, as concepções de direitos humanos 
de natureza não jurisdicista vão além da simples denúncia das ilusões homogeneizadoras que permitem à sociedade representar-se sob a imagem de uma ordem integrada, unívoca e coesa, sob a égide de um texto constitucional absolutizado em sua soberania. Elas, por exemplo, recolocam a idéia de justiça no centro das discussões - não uma justiça abstrata, fundada em critérios metafísicos ou transcendentes, mas uma justiça in fieri, pensada com base em situações concretas e perspectivas históricas específicas (FARIA, 2004, p. 12).

Portanto, em relação à defesa dos direitos fundamentais, o ponto convergente, tanto do discurso constante no texto constitucional brasileiro quanto no DIDH, é a dignidade humana. É essa, inclusive - além da própria previsão normativa (art. $5^{\circ}, \S \S 1^{\circ}$ ao $3^{\circ}$ ) -, que possibilita a leitura diferenciada dos tratados internacionais de direitos humanos em relação aos demais tratados. Essa conclusão advém de uma análise sistemática do próprio texto constitucional que eleva à categoria de princípio a "dignidade da pessoa humana" (art. $\left.1^{\circ}, \mathrm{III}\right)$, sugerindo ainda a prevalência dos direitos humanos nas relações internacionais (art. $4^{\circ}$, II) para, mais à frente, no art. $5^{\circ}, \S \S 1^{\circ}$ e $2^{\circ}$, garantir a aplicabilidade imediata aos tratados internacionais.

O princípio "da dignidade da pessoa humana" ainda segue fortemente ancorado na concepção filosófica kantiana, no sentido de que a pessoa (ser humano) deve ser sempre considerada como um fim e não como um meio, repudiando, assim, qualquer pretensão de coisificação ou instrumentalização do homem. Todavia, refutando a noção ontológica de dignidade, Hegel defende a necessidade de assunção da condição de cidadão para o ser humano atingir tal qualidade (dignidade), consubstanciando, desse modo, a máxima de que cada um deve respeitar os outros como pessoas, ou seja, a dignidade é (também) o resultado do reconhecimento. A partir desses aportes filosóficos, Sarlet aduz que a dignidade humana pode ser concebida como

A qualidade intrínseca e distintiva reconhecida em cada ser humano que o faz merecedor do mesmo respeito e consideração por parte do Estado e da comunidade, implicando, neste sentido, um complexo de direitos e deveres fundamentais que assegurem a pessoa tanto contra todo e qualquer ato de cunho degradante e desumano, como venham a lhe garantir as condições existenciais mínimas para uma 
vida saudável (parâmetros da Organização Mundial da Saúde), além de propiciar e promover sua participação ativa e co-responsável nos destinos da própria existência e da vida em comunhão com os demais seres humanos (SARLET, 2004, p. 59-60). ${ }^{24}$

Segundo Charles Taylor, as sociedades pré-modernas eram marcadas por uma forte divisão em castas, cujas hierarquias sociais se baseavam na honra - que é uma questão de preferências. Para que alguns a detenham, é essencial que outros não a possuam. Desse modo, quem a detém usufruía, na "pré-modernidade", de privilégios a que outros não tinham acesso. Dessa maneira, para Taylor, a substituição da noção antiga de honra pela noção de dignidade estendeu a possibilidade do reconhecimento a um nível muito mais abrangente:

Opõe-se a essa noção de honra a noção moderna de dignidade, agora usada num sentido universalista e igualitário que nos permite falar da 'dignidade [inerente] dos seres humanos' ou de dignidade dos cidadãos. A premissa de base aqui é de que todos partilham dela. É óbvio que esse conceito de dignidade é o único compatível com uma sociedade democrática [...] (TAYLOR, 1995, p. 226-227).

É dessa idéia inicial de amplitude da dignidade humana que a leitura hermenêutica do princípio da dignidade da pessoa humana na Constituição de 1988 deve considerar o valor da disposição topográfica de tal princípio, pois, como se nota, o legislador constituinte se encarregou de prever tal princípio logo na parte inaugural do texto, juntamente com os demais fundamentos da "Carta Cidadã". Dito de outra forma, com as palavras de Sarlet (2004, p. 61), entende-se que

[...] o Constituinte deixou transparecer de forma inequívoca a sua intenção de outorgar aos princípios fundamentais a qualidade de normas embasadoras e informativas de toda a ordem constitucional, inclusive (e especialmente), das normas definidoras de direitos e garantias fundamentais, que igualmente integram (juntamente com os princípios fundamentais) aquilo que se pode - e neste ponto parece haver consenso - denominar de núcleo essencial da nossa Constituição formal e material (SARLET, 1988, p. 61). ${ }^{25}$

Da mesma forma, ineditamente na história do constitucionalismo 
brasileiro, a dignidade humana foi reconhecida como fundamento do Estado Democrático de Direito (art. 1º, III, da Constituição de 1988), sendo ainda citada em vários outros capítulos do texto constitucional,

[...] seja quando estabeleceu que a ordem econômica tem por finalidade assegurar a todos uma existência digna (artigo 170, caput), seja quando, na esfera da ordem social, fundou o planejamento familiar nos princípios da dignidade da pessoa humana [...] (artigo 226, § $6^{\circ}$ ), além de assegurar à criança e ao adolescente o direito à dignidade (artigo 227, caput) (SARLET, 2004, p. 62).

Sintetizando, com Carlos Roberto Siqueira Castro, entendese que o Estado Constitucional Democrático da atualidade é um Estado de abertura constitucional radicado no princípio do ser humano (CASTRO, 2005). Neste momento, cabe aclarar que a noção apresentada alhures não se reduz a uma exposição metafísica daquilo que seja a "dignidade da pessoa humana", para utilizar a terminologia empregada pelo constituinte.

Isso porque, ao considerar o ser humano como pessoa (art. $1^{\circ}$, III; 17 , caput; 34, VII, b; 226, par. $7^{\circ}$ ), a Constituição - inserida na tradição ocidental (conforme se verificou na abordagem de Sarlet, com Kant e Hegel) - atribui-lhe traços constitutivos determinados: concretude/ historicidade, individualidade, racionalidade, sociabilidade. Essas dimensões da pessoa estabelecem alguns recursos como necessários para o pleno desenvolvimento ou para a vida digna do ser humano (liberdade, saúde, segurança, educação, etc.). Com isso, ao afirmar, no texto constitucional, a dignidade humana, o constituinte buscou colocar o ser humano como um credor de "bens" necessários para que ele alcance uma vida digna como pessoa, isto é, como ser concreto, individual, racional e social. A busca desses "bens" estabelece deveres de justiça para o Estado, para a sociedade e para a própria pessoa.

Assim, esses recursos necessários à vida digna, quando considerados na perspectiva da comunidade, são chamados de valores. Os valores integram o "bem comum", o conjunto de condições que permite a todos os membros da comunidade alcançarem a vida digna. Os valores formam o conteúdo dos deveres de justiça social. Assim, o desenvolvimento, como valor, deve orientar a atividade econômica pública e privada. Na medida em que a atividade econômica persegue 
o valor "desenvolvimento", ela é justa, isto é, atende às exigências da justiça social.

Contudo, o salutar processo de expansão da defesa dos direitos humanos no ambiente internacional, iniciado, conforme já se afirmou, principalmente a partir do II pós-guerra, a precariedade do cenário social de civilizações periféricas - como a brasileira, marcada por um quadro geral de "cidadanias precárias" - ainda sugere intervenções estatais básicas, nos moldes previstos pelo Constitucionalismodirigente, até porque a efetivação de direitos sociais passa, primordialmente, pelo Estado que, paradoxalmente, conforme afirma Rocha (Capítulo III), ainda é soberano.

Por isso, retornando-se à relação que deve se manter inexorável entre cidadania e atuação estatal dirigida pela Constituição, assumese a tese de que, tão importante quanto a atuação da jurisdição constitucional - referida alhures -, é o fomento de uma tradição hermenêutico-social de um sentimento constitucional, para a implementação dos "compromissos modernos" do Estado brasileiro, materializados nas promessas de garantias dos direitos sociais e nos objetivos expostos no texto constitucional.

Sobre o sentimento constitucional, Pablo Lucas Verdú - amparado pela teoria de Pellegrino Rossi - entende que este atua como um verdadeiro liame moral entre as instituições e os homens e, se essa vinculação moral falha, "[...] resulta que a) nada é sólido nem regular, b) não há cuidado na defesa da ordem estabelecida, c) nem espírito de continuidade nas reformas (VERDÚ, 2004). Não há como negar que a idéia de um sentimento constitucional remonta, em seu nascedouro, a visão burguesa liberal do século XVIII, mais especificamente datada de 1789, ocasião da Declaração do Direito do Homem e do Cidadão: "Toda a sociedade na qual não esteja assegurada a garantia dos direitos nem determinada a separação de poderes não possui Constituição". O ter (anseios populares veemente demonstrados) e o estar em (ordenação racional da convivência política) Constituição, foram sentimentos patentes de países que lutaram por independência (VERDÚ, 2004, p. 73-74).

Para países recém-saídos de experiências institucionais autoritárias, com Estados sociais omissos, uma concepção da Constituição 
Dirigente, condizente com os valores de um Estado Democrático de Direito, deve se fundamentar numa teoria que, por sua vez,

[...] já não pode ser só fruto da intelecção constitucional, senão, ademais, e em alguns momentos e casos muito significativamente, resultado da sensibilidade constitucional, de modo que a explicação das conexões normativo-institucionais do 'estar-em-Constituição' nunca hão de perder de vistas motivações emocionais do 'ter-Constituição' e de conviver conforme a Constituição.

A princípio, o sentimento constitucional consiste na adesão interna a normas e instituições fundamentais de um país, experimentada com intensidade mais ou menos consciente porque estimula-se (sem que seja necessário um conhecimento exato de suas peculiaridades e funcionamento) que são boas e convenientes para a integração, manutenção e desenvolvimento de uma justa convivência (VERDÚ, 2004, p. 74-75).

Por isso, além da noção da sua força normativa - legado da tradição constitucional européia do século XX (pós-II Guerra) -, a compreensão da Constituição como dirigente, programática e compromissária é fundamental para se atribuir sentido à relação Constituição-Estado-Sociedade (STRECK, 2004, p. 209) para se alcançar a finalidade maior desse "trinômio" que é o bem comum.

\section{SÍNTESE FINAL}

Com base nos argumentos desenvolvidos na pesquisa, ora materializada no presente projeto, logram-se alguns apontamentos conclusivos:

a) Com o advento da Constituição de 1988, inaugura-se um novo momento do constitucionalismo no Brasil, na medida em que, em face do conteúdo altamente comprometido com os ideais democráticos e com a defesa dos direitos humanos, promove-se uma verdadeira revolução no campo jurídico brasileiro. Essa revolução pode ser resumida na proposta de um resgate ético do direito como um todo, capitaneado pelo direito constitucional.

b) A partir do Estado Democrático de Direito sugerido pelo texto supracitado, a cidadania no Brasil deve ser reestruturada, principalmente à luz dos ideais transformadores desse modelo de 
Estado, que sugerem, principalmente, a melhoria das condições sociais no Brasil. Para tanto, a Carta assume uma postura compromissáriadirigente, com metas bem definidas, principalmente a favor daqueles que sempre se viram alijados de qualquer possibilidade de participação materialmente democrática no Estado e na sociedade.

c) Todavia há dificuldades para a materialização da democracia num modelo de sociedade em que boa parte dos "cidadãos" não são reconhecidos como integrantes do jogo democrático. Como conseqüência disso, percebe-se que falta no Brasil um sentimento constitucional que, inevitavelmente, acaba por comprometer a efetivação da própria Constituição dirigente, na medida em que este texto depende diretamente de uma cidadania ativista, capaz de, ao lado da própria Jurisdição constitucional, implementar as promessas descumpridas da modernidade.

d) Por fim, como proposta diferenciada para a leitura da problemática exposta acima, sugere-se, no presente texto, uma leitura hermenêutica das ações políticas que viabilize sair-se dos impasses deixados pelas concepções filosóficas de cunho hegemônico, no que se refere à identidade dos agentes morais e políticos.

\section{REFERÊNCIAS}

ARENDT, Hannah. O que é política? Tradução de Reinaldo Guarany. 3. ed. Rio de Janeiro: Bertrand Brasil, 2002.

ARISTÓTELES. Política. Tradução de Julian Marias e Maria Araújo. Madrid: Centro de Estudos Constitucionales, 1999.

BARRETTO, Vicente de Paulo. Direitos humanos e sociedades multiculturais. Anuário do Programa de Pós-Graduação em Direito - Mestrado e Doutorado. São Leopoldo: Unisinos, 2003. p. 459-483.

Leitura ética da Constituição. Texto disponibilizado na disciplina Ética e Fundamentação do Direito do Curso de Mestrado em Direito da UNISINOS-RS, 2004.

BAUMAN, Zygmunt. Comunidade: a busca por segurança no mundo atual. Tradução de Plínio Dentzien. Rio de Janeiro: Zahar, 2003. 
BAUMAN, Zygmunt. Modernidade líquida. Tradução: Plínio Dentzien. Rio de Janeiro: Zahar, 2001.

- Globalização: as conseqüências humanas. Tradução de Marcus Penchel. Rio de Janeiro: Zahar, 1999.

BERCOVICI, Gilberto. Teoria do Estado e teoria da Constituição na periferia do capitalismo. In: AVELÃS NUNES, António José; COUTINHO, Jacinto Nelson de Miranda (Org.). Diálogos constitucionais: Brasil/Portugal. Rio de Janeiro: Renovar, 2004. p. 263-290.

Constituição econômica e Constituição dirigente. In: BONAVIDES, Paulo; et al. Constituição e democracia: estudos em homenagem ao professor J. J. Gomes Canotilho. São Paulo: Malheiros, 2006. p. 219-251.

A Constituição dirigente e a crise da teoria da Constituição. In: SOUZA NETO, Cláudio Pereira de et al. Teoria da Constituição: estudos sobre o lugar da política no direito constitucional. Rio de Janeiro: Lumen Juris, 2003, v. 1, p. 75-150.

BINENBOJM, Gustavo. A nova jurisdição constitucional brasileira: legitimidade democrática e realização. 2. ed. Rio de Janeiro: Renovar, 2004.

BOBBIO, Norberto. O positivismo jurídico contemporâneo: lições de filosofia do direito. Tradução de Márcio Pugliesi et al. São Paulo: Ícone, 1995.

BONAVIDES, Paulo; ANDRADE, Paes de. História constitucional do Brasil. Brasília: Paz e Terra, 1989.

Do país constitucional ao país neocolonial: a derrubada da Constituição e a recolonização pelo golpe institucional. 2. ed. São Paulo: Malheiros, 2001.

CANÇADO TRINDADE, Antonio Augusto. Tratado de direito internacional dos direitos humanos. Porto Alegre: Fabris, 1997. v. 1 e 2 .

CANOTILHO, J. J. Gomes. Constituição dirigente e vinculação do legislador. Coimbra: Almedina, 2001. 
CANOTILHO, José Joaquim Gomes. Revisar o romper com la Constitucion dirigente? Defensa de un constitucionalismo moralmente reflexivo. Revista Española de Derecho Constitucional, Madrid, n. 43, p. 9-23, jan./abr. 1995.

CASTRO, Carlos Roberto Siqueira. O princípio da dignidade da pessoa humana nas Constituições abertas e democráticas. In: CAMARGO, Margarida Maria Lacombe. 1988 - 1998: uma década de Constituição Rio de Janeiro: Renovar, 1999. p. 103-114.

CASTRO, Carlos Roberto Siqueira. A Constituição aberta e os direitos fundamentais: ensaios sobre o constitucionalismo pós-moderno e comunitário. Rio de Janeiro: Forense, 2005.

CHAUÍ, Marilena. Apresentando o livro de Lefort. In: LEFORT, Claude. A invenção democrática. Tradução de Isabel M. Loureiro. São Paulo: Brasiliense, 1983.

CITTADINO, Gisele. Pluralismo, direito e justiça distributiva: elementos da filosofia constitucional contemporânea. 3. ed. Rio de Janeiro: Lumen Juris, 2004.

COMPARATO, Fábio Konder. Ética: direito, moral e religião no mundo moderno. São Paulo: Companhia das Letras, 2006.

COUTINHO, Jacinto Nelson de Miranda (Org). Canotilho e a Constituição dirigente. 2. ed. Rio de Janeiro: Renovar, 2005.

COUTINHO, Jacinto Nelson de Miranda; AVELÃS NUNES, Antônio José. Diálogos constitucionais: Brasil/Portugal. Rio de Janeiro: Renovar, 2004.

DEZALAY, Ives; TRUBEK, David M. A restruturação global e o Direito. In: FARIA, José Eduardo (Org.). Direito e globalização econômica: implicações e perspectivas. São Paulo: Malheiros, 1998, p. 29-80.

FARIA, José Eduardo. Prefácio. In: BALDI, César Augusto (org.). Direitos humanos na sociedade cosmopolita. Rio de Janeiro: Renovar, 2004. p. 1-13.

GADAMER. Hans-Georg. Verdad y método I. Salamanca: Ediciones Síngueme, 1994. 
GOMES, José Maria. Política e democracia em tempos de globalização. Rio de Janeiro: Vozes, 2000.

GRAU, Eros Roberto. Resenha do Prefácio Segunda Edição. In: COUTINHO, Jacinto Nelson (org.). Canotilho e a Constituição dirigente. 2. ed. Rio de Janeiro: Renovar, 2005.

GUEDES, Néviton. In: COUTINHO, Jacinto Nelson (Org.). Canotilho e a Constituição dirigente. 2. ed. Rio de Janeiro: Renovar, 2005.

HABERMAS, Jüngen. A inclusão do outro: estudos de teoria política. São Paulo: Loyola, 2002.

Direito e moral. Tradução de Sandra Lippert. Lisboa: Instituto Piaget, 1992.

Eurocentrismo, Europa dos mercados ou Europa dos cidadãos (do Mundo). Rio de Janeiro: Tempo Brasileiro, 1999.

IANNI, Octávio. Teorias da globalização. Rio de Janeiro: Civilização Brasileira, 1999.

JOBIN, Nelson. Dura lex, sed o mundo gira. Primeira Leitura, São Paulo, ano 3, n. 32, out. 2004.

KELSEN, Hans. Teoria pura do direito. Tradução de João Baptista Machado. 6. ed. Coimbra: Armênio Amado, 1984.

LAFER, Celso. A reconstrução histórica dos direitos humanos: um diálogo com o pensamento de Hannah Arendt. São Paulo: Companhia das Letras, 1999.

LEFORT, Claude. Os direitos do homem e o Estado-Providência. Tradução de Eliana M. Souza. In: Pensando o político: ensaios sobre democracia, revolução e liberdade. Rio de Janeiro: Paz e Terra, 1991. p. 37-62.

MARX, Karl. A questão judaica. Tradução de Silvio Donizete Chagas. 4. ed. São Paulo: Centauro, 2002.

MATTEUCCI, Nicola. Soberania. In: BOBBIO, Norberto et al. Dicionário de política. Traduzido por João Ferreira. 5. ed. Brasília: EdUNB, 2000. p. 1179-1188. 
MELLO, Celso Duvivier de Albuquerque. Curso de direito internacional público. 12. ed. Rio de Janeiro: Renovar, 2000.

MENDES, Gilmar Ferreira. Jurisdição constitucional. 3. ed. São Paulo: Saraiva, 1999.

MORAIS, Jose Luis Bolzan de; STRECK, Lenio Luiz. Ciência política e teoria geral do Estado. 2. ed. Porto Alegre: Livraria do Advogado, 2001.

As crises do Estado e da Constituição e a transformação espacial dos direitos humanos. Porto Alegre: Livraria do Advogado, 2002.

MORAIS, José Luiz Bolzan de; STRECK, Lenio Luiz. Direitos humanos "globais (universais)". De todos, em todos os lugares! In: ANUÁRIO do Programa de Pós-Graduação em Direito - Mestrado e Doutorado. São Leopoldo: EdUnisinos, 2001. p. 43-76.

NEVES, Marcelo. Constitucionalização simbólica e descontitucionalização fática: mudança simbólica da Constituição e permanência das estruturas reais de poder. Revista Trimestral de Direito Público, São Paulo, n. 12, p. 156-67, 1995.

- Entre Têmis e Leviatã: uma relação difícil: o Estado Democrático de Direito a partir e além de Habermas e Luhmann. São Paulo: Martins Fontes, 2006.

ORWELL, George. Inglaterra, tua Inglaterra. In BAUMAN, Zigmunt. Modernidade e Holocausto. Tradução Marcus Penchel. Rio de Janeiro: Zahar, 1998.

OST, François. O tempo do direito. Tradução Maria Fernanda Oliveira. Lisboa: Instituto Piaget, 1999.

PIOVESAN, Flávia. Direitos humanos e o direito constitucional internacional. 7. ed. São Paulo: Saraiva, 2006.

PIOVESAN, Flávia. Direitos humanos, o princípio da dignidade humana e a Constituição Brasileira de 1988. Revista do Instituto de Hermenêutica Jurídica - (Neo)Constitucionalismo: ontem, os códigos, hoje as Constituições. Porto Alegre, v. 1, n. 2, jan. 2004, p. 79-100. 
ROCHA, Leonel Severo. Epistemologia jurídica e democracia. 2. ed. São Leopoldo: EdUNISINOS, 2003.

. O direito na forma de sociedade globalizada. In: ANUÁRIO do Programa de Pós-Graduação em Direito - Mestrado e Doutorado. São Leopoldo: EdUnisinos, 2001. p. 118.

ROCHA, Leonel Severo. Forma de sociedade, cultura política e democracia. In: Epistemologia jurídica e democracia. 2. ed. São Leopoldo: Unisinos, 2003. p. 180.

ROCHA, Leonel Severo et al. Introdução à teoria do sistema autopoiético do direito. Porto Alegre: Livraria do Advogado, 2004.

ROTH, André-Noël. O direito em crise: fim do Estado moderno?. In: FARIA, José Eduardo (Org.). Direito e globalização econômica: implicações e perspectivas. São Paulo: Malheiros, 1998. p. 15-28.

SANTOS, Boaventura de Sousa. A crítica da razão indolente: contra o desperdício da experiência. 4. ed. São Paulo: Cortez, 2002.

SARLET, Ingo Wolfgang. Dignidade da pessoa humana e direitos fundamentais na constituição Federal de 1988. 3. ed. Porto Alegre: Livraria do Advogado, 2004.

SILVA, José Afonso da. Curso de direito constitucional positivo. 15. ed. São Paulo: Malheiros, 1998.

SILVA, Juremir Machado da. In: LIPOVETSKY, Gilles. A sociedade pós-moralista: o crepúsculo do dever e a ética indolor dos novos tempos democráticos. Tradução de Armando B. Ara. Barueri (SP): Manole, 2005.

STRECK, Lenio Luiz. Hermenêutica jurídica e(m) crise. 3. ed. Porto Alegre: Livraria do Advogado, 2001.

STRECK, Lenio Luiz. Jurisdição constitucional e hermenêutica: uma nova crítica do direito. 2. ed. Rio de Janeiro: Forense, 2004.

A concretização de direitos e a validade da tese da Constituição dirigente em Países de modernidade tardia. In: AVELÃS NUNES, António José; COUTINHO, Jacinto Nelson de Miranda (Org.). Diálogos constitucionais: Brasil/Portugal. Rio de Janeiro: Renovar, 2004. p. 301-371 
STRECK, Lenio Luiz. Verdade e consenso: constituição, hermenêutica e teorias discursivas. Rio de Janeiro: Lumen Juris, 2005.

TAVARES, André Ramos. Teoria da justiça constitucional. São Paulo: Saraiva, 2005.

TAYLOR, Charles. A política do reconhecimento. In:

Argumentos filosóficos. Tradução de Adail U. Sobral. São Paulo: Loyola, 2000. p. 241-274.

- The politics of recognitions. In:

Philosophic arguments. Massachusetts: Havard University Press, 1995. p. 225-256.

UNGER, Roberto Mangabeira. $\mathrm{O}$ direito na sociedade moderna. Rio de Janeiro: Civilização Brasileira, 1979.

VERDÚ, Pablo Lucas. Sentimento constitucional: aproximação ao estudo do sentir constitucional como modo de integração política. Tradução de Agassiz A. F. Rio de Janeiro: Forense, 2004.

VIEIRA ANDRADE, José Carlos. Os direitos fundamentais na Constituição Portuguesa de 1976. 3. ed. Coimbra: Almedina, 2004.

WALZER, Michael. As esferas da justiça. São Paulo: Martins Fontes, 2003.

WARAT, Luis Alberto. O direito e sua linguagem. Porto Alegre: Fabris, 1995.

. Introdução geral ao direito: interpretação da lei: temas para uma reformulação. Porto Alegre: SAFE, 1994. v. 1, p. 53.

WOLKMER, Antonio Carlos. Ideologia, Estado e Direito. 2. ed. São Paulo: RT, 1995.

\section{NOTAS}

1 Por todos, STRECK, Lenio Luiz. Jurisdição constitucional e hermenêutica: uma nova crítica do direito. 2. ed. Rio de Janeiro: Forense, 2004.

2 Kelsen pode ser considerado um neopositivista, “[...] pois postula uma ciência do Direito alicerçada em proposições normativas que descrevem sistematicamente o objeto do Direito. Trata-se de uma metateoria do Direito, que, ao contrário do positivismo legalista dominante na tradição jurídica (que confunde lei e direito), propõe uma ciência do Direito como uma metalinguagem distinta de seu objeto". 
Cf. ROCHA, Leonel Severo. "Três matrizes teóricas do direito". In: Epistemologia jurídica e democracia. 2. ed. São Leopoldo: EdUnisinos, 2003. p. 96.

3 Cf. também: BARZOTTO, Luis Fernando. O positivismo jurídico contemporâneo: Uma introdução a Kelsen, Ross e Hart. São Leopoldo: Ed. Unisinos, 2000, p. 19-20.

4 Termo empregado por Lenio Luiz Streck como alusão ao modelo de racionalidade jurídica difundido a partir do movimento liberal europeu do século XVIII. Cf. Hermenêutica jurídica e $(m)$ crise: uma exploração hermenêutica da construção do direito. 3. ed. Porto Alegre: Livraria do Advogado, 2001, p. 63-64.

5 Segundo Dezalay e Trubek, o modo de produção do Direito inclui: “[...] a) o modo com que a profissão jurídica e a prestação de seus serviços são organizadas; b) a localização de papéis entre as várias posições no campo jurídico (praticantes, aplicadores da lei, acadêmicos, etc.); c) o modo com que o campo produz o habitus, incluindo variações na educação e a importância das vantagens sociais (antecedentes e relações pessoais) para recrutamento no campo; d) as modalidades para a articulação da doutrina preponderante e os modos com que estas incidem em relações entre jogadores e posições; e) o papel que os advogados, juntamente com os protagonistas globais e regimes transnacionais representam num dado campo jurídico; f) a relação entre regulação e proteção; g) o modo dominante de legitimação. DEZALAY, Ives; TRUBEK, David M. A reestruturação global e o direito. In: FARIA, José Eduardo. Direito e globalização econômica: implicações e perspectivas. São Paulo: Malheiros, 1998, p. 39-40.

6 "A idéia de formalismo põe em relevo os motivos mais profundos que inspiram esta busca de governo sob a lei. Para o formalismo, o cerne do direito é um sistema de regras gerais, autônomas, públicas e positivas que limitam, ainda que não determinem inteiramente, aquilo que um indivíduo pode fazer como autoridade ou como pessoa privada" (UNGER, Roberto Mangabeira. O direito na sociedade moderna: contribuição à crítica da teoria social. Rio de Janeiro: Civilização Brasileira, 1979. p. 213-14).

7 Octávio Ianni, apresentando "metáforas da globalização", comenta que "A fábrica global instala-se além de toda e qualquer fronteira, articulando capital, tecnologia, força de trabalho, divisão do trabalho social e outras forças produtivas. Acompanhada pela publicidade, a mídia impressa e eletrônica, a indústria cultural, misturadas em jornais, revistas, livros, programas de rádio, emissões de televisão, videoclipe, fax, redes de computadores e outros meios de comunicação, informação e fabulação, dissolve fronteiras, agiliza os mercados, generaliza o consumismo. Provoca a desterritorialização e a reterritorialização das coisas, gentes e idéias. Promove o redimensionamento de espaços e tempos" (IANNI, Octávio. Teorias da globalização. 5. ed. Rio de Janeiro: Civilização Brasileira, 1999. p. 19). Não é o propósito principal deste trabalho aprofundar a discussão sobre os efeitos e as perspectivas da globalização em relação aos direitos humanos, todavia, partindose dessa observação de Octávio Ianni, é necessário reforçar que a globalização, justamente por proporcionar o desmanche de fronteiras, impondo, assim, uma revisão sobre o conceito de soberania absoluta e cidadania, sugere uma (re)visão da 
possibilidade de universalidade dos direitos humanos, para além da perspectiva da jurisdição doméstica.

8 Sobre a questão democrática cf. MORAIS, Jose Luis Bolzan de; STRECK, Lenio Luiz. Ciência política e teoria geral do Estado. 2. ed. Porto Alegre: Livraria do Advogado, 2001. p. 100-127.

9 No âmbito normativo, a preocupação com o princípio da igualdade humana encontra inspiração em diversos textos constitucionais do século XX, por exemplo, a Constituição do México de 1917, art. 3, II, “c", a da Itália de 1947, art. 3, e de Portugal de 1976 , art. $1^{\circ}$, bem como nos instrumentos normativos internacionais, como, por exemplo, na Declaração dos Direitos do Homem de 1948, art. $1^{\circ}$.

10 Sobre a lei no Estado Democrático de Direito, ver SILVA, José Afonso da. Curso de direito constitucional positivo. 15. ed. São Paulo: Malheiros, 1998, p. 125-126.

11 WALZER, Michael. As esferas da justiça. São Paulo: Martins Fontes, 2003.

12 TAYLOR, Charles. The politics of recognition. In:

Philosophical Arguments. Massachusetts: Harvard University Press, 1995. p. 225-256.

13 É válido mencionar que a Constituição de 1988 “foi receptiva de toda sorte de demandas da sociedade civil, traumatizada por 20 anos de arbítrio, o que lhe valeu a visível e benéfica influência das Constituições de Portugal, de 1976, e da Espanha, de 1978. Tal se deveu não apenas em função dos laços histórico-culturais que associam a formação do Brasil à península ibérica, mas sobretudo ao fato de que essas nações, por igual, emergiram de longo e traumatizante período ditatorial - o Salazarismo e o Franquismo - tendo buscado, na seiva da Constituinte, um nutriente de redemocratização e pacificação nacional" (CASTRO, Carlos Roberto Siqueira. A Constituição Aberta e os Direitos Fundamentais: ensaios sobre o constitucionalismo pós-moderno e comunitário. Rio de Janeiro: Forense, 2005. p. 117 e 127).

14 Cf. GUEDES, Néviton. In COUTINHO, Jacinto Nelson (org.). Canotilho e a Constituição dirigente. 2. ed. Rio de Janeiro: Renovar, 2005, p. 6; STRECK, Lenio Luiz. A Concretização de Direitos e a Validade da Tese da Constituição Dirigente em Países de Modernidade Tardia, p. 301-71. In: AVELÃS NUNES, António José; COUTINHO, Jacinto Nelson de Miranda (orgs.). Diálogos Constitucionais: Brasil/ Portugal. Rio de Janeiro: Renovar, 2004, p. 331.

$15 \mathrm{O}$ artigo referido foi: CANOTILHO, J. J. Gomes. Revisar o Romper com la Constitucion Dirigente? Defensa de un constitucionalismo moralmente reflexivo. In Revista Española de Derecho Constitucional, ano 15, nº 43, 1995.

16 Acerca da modernidade tardia e duas conseqüências no campo jurídico, vide, em especial, o capítulo 1, de STRECK, Lenio Luiz. Hermenêutica jurídica e(m) crise: uma exploração hermenêutica da construção do Direito. 5. ed. Porto Alegre: Livraria do Advogado, 2004. Sobre a necessidade de adequação temporal e espacial da Constituição, Bercovici afirma que, "Fechando os olhos para a realidade constitucional, o pensamento jurídico positivista absolutizou as soluções constitucionais históricas do liberalismo como atemporais. Para não cair neste equívoco, a Teoria da 
Constituição deve ser entendida na lógica das situações concretas históricas de cada país, integrando em um sistema unitário a realidade histórico-política e a realidade jurídica" (Cf. BERCOVICI, Gilberto. A Constituição dirigente e a crise da teoria da Constituição. In: Teoria da Constituição: estudos sobre o lugar da política no direito constitucional. Rio de Janeiro: Lumen Juris, 2003, p. 131-132.

17 Como mostra Juremir Machado da Silva: “A solidariedade, mostra Lipovetsky, toma novas formas e ganha o planeta em campanhas humanitárias transmitidas pela televisão. Mesmo o humanitário, esse pensar nos outros, acontece sob a forma de espetáculo. Por que não? Já não se quer ser santo pela prática de boas ações. Podese admirar Madre Teresa de Calcutá sem querer viver como ela. Acabou a época da devoção absolutamente desinteressada. Nesta era da solidariedade espetacularizada, cada um faz da sua doação uma forma de ganho, de vibração, de visibilidade, talvez até de marketing." . In LIPOVETSKY, Gilles. A sociedade pós-moralista: o crepúsculo do dever e a ética indolor dos novos tempos democráticos. Traduzido por Armando B. Ara. Barueri (SP): Manole, 2005, p. XVII.

18 Em relação ao Brasil e a todos os países periféricos e semi-periféricos, a crise é ainda mais dramática, porque, como já se afirmou, o Estado social foi um simulacro na medida em que sua implementação foi altamente precária e insuficiente. Contudo as medidas tomadas, principalmente na última década do século $\mathrm{XX}$, apontam o "desmonte do Estado", numa tentativa de reduzi-lo a um modelo "minimizado", "enxuto", sem nunca ter sido, de fato, generoso socialmente, tal qual o modelo francês, por exemplo. Como nota Bercovici (2004, p. 275) “O Estado brasileiro, constituído após a Revolução de 1930, é, portanto, um Estado estruturalmente heterogêneo e contraditório. É um Estado Social sem nunca ter conseguido instaurar uma sociedade de bem-estar: moderno e avançado em determinados setores da economia, mas tradicional e repressor em boa parte das questões sociais".

19 MORAIS, Jose Luis Bolzan de. As Crises do Estado e da Constituição e a Transformação Espacial dos Direitos Humanos. Porto Alegre: Livraria do Advogado, 2002, p. 48. Sobre este assunto, Streck defende a necessidade de uma "resistência constitucional", adotando uma postura substancialista, capaz de contribuir para o cumprimento de promessas adotadas na Carta Magna brasileira, que foram pouco (ou nada!) cumpridas na realidade tupiniquim (STRECK, Lenio Luiz, 2004, p. 6677). Nesse sentido, cf., também: BONAVIDES, Paulo. Do país constitucional ao país neocolonial: a derrubada da Constituição e a recolonização pelo golpe institucional. 2. ed. São Paulo: Malheiros, 2001, p. 44-46.

20 Sobre as críticas à concepção discursivo-procedimental, especialmente a habermasiana, v. STRECK, Lenio Luiz. Verdade e Consenso: Constituição, Hermenêutica e Teorias Discursivas. Rio de Janeiro: Lumen Juris, 2006.

21Sobre a atuação da Jurisdição Constitucional a partir do modelo de Estado Democrático de Direito brasileiro e seus desdobramentos, vide, dentre outros: BINENBOJM, Gustavo. A nova jurisdição constitucional brasileira: legitimidade democrática e realização. 2. ed. Rio de Janeiro: Renovar, 2004; MENDES, Gilmar 
Ferreira. Jurisdição constitucional. 3. ed. São Paulo: Saraiva, 1999; TAVARES, André Ramos. Teoria da justiça constitucional. São Paulo: Saraiva, 2005. Para uma análise filosófico-constitucional mais aprofundada, vide: STRECK, Lenio Luiz. Jurisdição constitucional e hermenêutica.

22 Na doutrina nacional, dentre outros: CANÇADO TRINDADE, Antonio Augusto. Tratado de direito internacional dos direitos humanos. Porto Alegre: Fabris, 1997. v. 1 e 2; MELLO, Celso D. de Albuquerque. Direito constitucional internacional. 2. ed. Rio de Janeiro: Renovar, 2000; PIOVESAN, Flávia. Direitos humanos e o direito constitucional internacional. 7. ed. São Paulo: Saraiva, 2006.

23 Ver também MORAIS, Jose Luis Bolzan de. Direitos humanos "globais (universais)". De todos os lugares! Anuário do Programa de Pós-Graduação em Direito - Mestrado e doutorado. São Leopoldo: EdUnisinos, 2001. p. 71.

24 Cf., também, BARRETO, Vicente de Paulo. Direitos humanos e sociedades multiculturais. Anuário do Programa de Pós-Graduação em Direito - Mestrado e Doutorado, 2001, p. 474.

25 No mesmo sentido, cf. PIOVESAN, Flávia. Direitos humanos, o princípio da dignidade humana e a Constituição Brasileira de 1988. Revista do Instituto de Hermenêutica Jurídica, Porto Alegre, v. 1, n. 2, p. 89-92, janeiro 2004.

Artigo Recebido em: 06/05/2008

Aprovado em: 26/06/2008 